\title{
The Resilient Smart City Model-Proposal for Polish Cities
}

\author{
Małgorzata Baran ${ }^{1, * \mathbb{D}}$, Monika Kłos ${ }^{2}{ }^{\mathbb{D}}$, Monika Chodorek ${ }^{3}$ and Karolina Marchlewska-Patyk ${ }^{3}$ \\ 1 Management Department, Collegium Civitas, 00-901 Warsaw, Poland \\ 2 Nadnotecki Institut, Adam Mickiewicz University, 61-712 Poznan, Poland; monika.klos@amu.edu.pl \\ 3 Department of Finance and Management, WSB University, 87-100 Torun, Poland; \\ monika.chodorek@wsb.torun.pl (M.C.); kmarchlewska@gmail.com (K.M.-P.) \\ * Correspondence: malgorzata.baran@civitas.edu.pl
}

check for

updates

Citation: Baran, M.; Kłos, M.;

Chodorek, M.; Marchlewska-Patyk,

K. The Resilient Smart City

Model-Proposal for Polish Cities.

Energies 2022, 15, 1818. https://

doi.org/10.3390/en15051818

Academic Editors: Elena Rytova,

Svetlana Gutman and Daniele

D. Giusto

Received: 14 January 2022

Accepted: 23 February 2022

Published: 1 March 2022

Publisher's Note: MDPI stays neutral with regard to jurisdictional claims in published maps and institutional affiliations.

Copyright: (C) 2022 by the authors. Licensee MDPI, Basel, Switzerland. This article is an open access article distributed under the terms and conditions of the Creative Commons Attribution (CC BY) license (https:// creativecommons.org/licenses/by/ $4.0 /)$.

\begin{abstract}
The smart city (SC) concept is currently one of the leading ideas in the field of management. It has also become important for Polish cities in terms of sustainable development. Therefore, it is important to determine the priority in urban development; and the areas that need investment to make cities smart. Based on the literature review, it can be stated that there are many available concepts of SCs since the level of development of many cities in the world is different and the priorities of the developed areas vary. The identified SC management models present common parts, resulting from the defining basis, as well as additional aspects important for an SC, stemming from their specificity and the approach of their managers. Thus, the aim of the article is to propose the author's model of resilient smart city development in Poland. To achieve the objective, a systematic literature review was applied, and the analysis of existing SC management models in the world was carried out in order to identify these models components and documents profiling SC strategies. These areas should be the focus of managers when creating city development strategies in Poland.
\end{abstract}

Keywords: smart city; sustainability; models; resilient smart cities model

\section{Introduction}

In today's economy, the concept of "sustainability" has become important to every individual who wants to grow. Sustainability is becoming a priority for governments [1], businesses [2], institutions [3] and people [4]. It also includes cities. The smart city concept is one of the leading management ideas to follow the path of sustainable development. It is estimated that $66 \%$ of the world's population will live in cities by 2050 , which will lead to cities facing colossal population and urban growth challenges. This trend places sustainable urban development and efficient urban management among the top priorities of urban administration, where socio-economic prosperity and environmental sustainability are the new mottos for cities in the era of globalized knowledge economy [5,6].

A systematic literature review reveals a multiplicity of smart city concepts and definitions [7-10]. One popular definition presents SCs as being claimed to provide such an effective model with their successful management capabilities accompanied by the stimulus and location for the world's creativity and innovation along with providing high quality of life and place, and low impact on the environment [11,12]. It is important to note that the concept of an SC is changing and evaluating, and successive authors are adding specific features to SCs [13]. New descriptors/necessary features to become smart appear, such as smart economy, smart mobility, smart environment, smart people, smart living and smart management [14,15], and use of technology for human systems and services [14]. Such targeting of the development of important areas and relevant investments allows cities to reach higher and higher levels of development and become next-generation smart cities in which residents and their well-being become increasingly important [16].

What areas are key to becoming a smart city? What should be the development priority of such cities? The characteristics of many smart cities around the world reveal the 
priority areas that city managers focus on. This has led to the development of a number of smart city management models. These models are more or less detailed, and their components differ in the metrics used to measure them and also have varied some of their components, which may indicate different priorities in city development [17-20]. These models currently lack reference to aspects such as entity resilience (e.g., to crises) or COVID-19, which should be considered when updating existing models. Smart cities should be resilient. The concept itself is capacious and has undergone conceptual evolution from a connection with nature [21] to urban planning issues [22]. Nowadays, the concept of resilience pays significant attention to the use of technological advances to improve the well-being of societies, linking together three elements: the creativity of people, institutions that facilitate knowledge sharing, and information and communication technologies (ICTs) that support the creation of innovations [23]. All these issues are taken into account by the concept presented by V. Niaros. The author of the concept presented different types of smart cities, distinguishing among them resilient smart cities. The approach presented by Niaros focuses on city managers' support of new forms of participatory planning and management, in which social and cultural factors are important [24]. This approach became an inspiration for the authors of the article, who used it while realizing the objectives of the article.

Polish cities also aim to become smart and take actions combining economic development with care for the environment and social friendliness. The existing global or European rankings show the position of selected Polish cities and, consequently, the level of advancement of the city's development towards becoming smart [3,25-27]. Therefore, it becomes important to indicate the areas which should be a priority in investment and development decisions, taking into account their environmental, location or social specifics. Therefore, the aim of the paper is to present the author's model of a resilient smart city for Polish cities. This will be achieved by identifying the dimensions of smart cities included in the existing models and benchmarking polish cities based on the existing rankings. Achieving the main objective is possible by realizing the following specific objectives:

- Identification of smart city models based on literature review;

- Typology of smart city models and benchmark of good practices;

- Identification of smart city dimensions based on systematic literature review;

- Identification of cities in Poland complying with the smart city concept;

- Indication of the position of Polish cities in selected European and world rankings reflecting the level of smartization process.

The following research methods were used in this study: a systematic review of the literature on the subject with the indication of the smart city and smart city management models, a review of official documents, reports and websites characterizing smart city strategies, as well as benchmarking criteria and characteristics of smart cities and heuristic methods to develop a resilient smart city model for Polish cities.

\section{Literature Review}

\subsection{Smart City Concept}

The development of the smart city concept, the multiplicity of approaches and the diversity of definitions of smart cities require knowing the current state of knowledge and identifying recommendations for further research. This became the rationale for using a systematic literature review [28]. According to the adopted methodology, the procedure was carried out in three stages: definition of the database and the set of publications; selection of publications, elaboration of the final publication database; bibliometric and content analysis of selected materials. Publications for analysis were collected from the Scopus database. Scientific publications (articles, book chapters) that contained the phrases (smart city* or smart cities*) were searched. The search at this stage resulted in over 5873 publications in total. In a second step, the following selection criteria were applied: publications in the field of business, management and accounting; publications containing the words "smart city" or "smart cities" in the title and/or in the abstract; publications 
published between 1999 and 2021; publications in English. This allowed the number of publications to be narrowed down for in-depth substantive analysis, which was carried out in the third stage of the systematic literature review. An accumulated collection of 245 publications was used for this purpose.

Despite the fact that in the public debate the concept of smart city appeared in the 1990s and was associated with the Smart Growth movement, promoting new principles of urban planning, until now there is no clear and universal definition of it in the literature [29-39]. According to experts, it should be explained by the multiplicity of aspects of urban development and the fact that the smart city is a relatively new concept with a wide spectrum of elements. What is more, the concept itself has been so democratized that different institutions emphasize different elements of it [37,40-45].

As the basis of competitiveness is innovation, smart ICT solutions have also become the starting point of the smart city $[29,46]$. Originally, this model was considered from the perspective of technology and hard infrastructure, but this was too much of a generalization. The researcher who first set out to define the concept of a smart city in 1999 was Arun. According to him, the basis of this concept is information technology, while an integral part of this vision is a concern for the quality of life of the ordinary citizen [47]. In September 2000, at the 2nd International Life Extension Technology Workshop, a broader definition of smart city was proposed by Hall. According to the researcher, a smart city is a city that monitors and integrates the conditions of all its critical infrastructures, such as roads, bridges, tunnels, railroads, subways, airports, seaports, communications, water, energy, so that it can better optimize its resources, plan preventive maintenance activities and monitor safety aspects while maximizing services to citizens [48]. On the other hand, in the work of Azkuna Smart Cities Study: International study on the situation of ICT, innovation and knowledge in cities, we can learn that a smart city is "a city that uses information and communication technologies to increase the interactivity and efficiency of urban infrastructure and its components, as well as to raise the awareness of citizens" [49]. In this view, Azkuna notes that the smart city should emphasize technology and the need to use it to improve infrastructure, as well as the need to invest in human capital to improve quality of life and promote sustainability. In a similar vein, but with a slightly broader focus on smart cities, we can read in a study by the Massachusetts Institute of Technology (MIT), which conducted research on smart cities between 2003 and 2010. Researchers from MIT define a smart city as an intelligence, a kind of subsystem, which consists of high-efficiency digital telecommunication networks-comparable to human nerves, ubiquitous intelligence- equivalent to brain, sensors and markers-similar to sense organs, and software-corresponding to knowledge and cognitive competence. What is important, this intelligence cannot function independently, in isolation from other urban systems. This means that in order to create new intelligence in cities, we need to bring together software and digital telecommunication networks, ubiquitously embedded intelligence, and sensors and tags $[8,50]$.

An important aspect of the smart city was highlighted by subject researchers Glasmeier and Christopherson. They pointed out that although the model has many meanings, in reality, it is two attributes that matter. The first is the use of technology to coordinate dispersed urban subsystems, and the second is the use of experience to create a new and better reality [51]. A similar position is taken by Leydesdorff and Deakin, who in their article The Triple Helix Model of Smart Cities: a neo-evolutionary perspective emphasized that building smart spaces is a joint venture of residents, local entrepreneurs and local government. The effects of these interactions create dynamic spaces in cities where knowledge can be used to trigger technologies of regional innovation systems [52].

A slightly different perspective on the smart city approach is presented by Komninos, a researcher and author of numerous publications on this concept. He emphasizes that this type of city is a space that shows learning capabilities, is oriented towards innovation, management and problem solving, and is creative [53]. He distinguished four basic dimensions of smart city, which refer to the application of ICT in building a digital city, the use of 
ICT to improve living and working conditions, the application of ICT in advanced urban infrastructure, and the integration of ICT with human capital to stimulate innovation and the accumulation and sharing of knowledge [54-58]. On the other hand, Winters, dealing with smart compaction, analyzes the smart city model through the lens of a multifunctional layout, being of the opinion that it is a metropolitan area with a high proportion of the adult population with higher education [59]. He thinks that smart cities are often centers of higher education, and students who move there, play an important role as they stay after graduation, which has a significant impact on the centers' further development.

One of the better-known pioneers of smart cities in Europe is Nijkamp. He indicates that smart cities are the result of strategies to improve the socio-economic, environmental, logistical and competitive performance of cities. According to the author, they are based on a combination of human, infrastructural, social and entrepreneurial capital $[60,61]$.

Writing about the European approach to shaping the smart city model, several important documents should be mentioned [62]. The first of them was the Strategic Energy Technology Plan, and the next one Energy 2020-strategies for competitive, sustainable and secure energy. In these documents we can read that achieving energy efficiency in Europe is possible by transforming the transport system, building and energy networks in cities, strengthening the efficiency of energy supply and integrating research and innovation activities [63,64]. Meanwhile, in September 2013, the Opinion of the Committee of the Regions on "Smart Cities and Communities-A European Innovation Partnership" was published in the Official Journal of the European Union (No. 2013/C 280/06) [65]. The document stressed that the Union faces one of the most important challenges in the coming years, which is to transform its cities into sustainable living environments in social, economic and environmental terms. This in turn implies the need for systems integration and interoperability as a basis for building a smart city.

These facts are especially important for Poland, where the idea of a smart city is still in the development stage. In this context, the greatest difficulty for Poland is to develop and then implement comprehensive, relating to the economic, social, environmental and spatial spheres, innovative development initiatives [36]. This process was assisted, among others, by EU funds in the framework of grants from the Operational Programme Digital Poland or Regional Operational Programmes. In 2017, the Ministry of Development also launched a grant competition for local government units under the Human Smart Cities initiative. Smart Cities are co-created by citizens [66]. The hope remains that every year Polish cities will become more and more "smart", which will result in them starting to rank high in international rankings.

When analyzing the smart city concepts, it should be noted that in the scientific literature it is increasingly defined as an urban system that aims to simultaneously invest in internet technologies, human capital and communication infrastructure and, at the same time, promote economic development and high quality of life [13,67-69]. We can also meet with other terms referring directly to the idea of a smart city. Researchers dealing with this topic also use related terms such as: intelligent city [70], knowledge city [11], digital city [71], creative city [72,73], green city [74]. There are also such proposals as human smart cities or the city of the future [75]. Other terms, sometimes used interchangeably with smart cities, include social cities and u-city, understood as a place where smart technology is an integral part of the urban fabric and its systems [76]. There is also no shortage of terms such as wired, digital and information cities [77,78].

Analyzing various smart city concepts, it is evident that it is a sustainable city in which the quality of life is systematically improved, the environment is more friendly to its inhabitants, and the prospects for economic development are at a high level [15]. Intelligence, which can be understood as the sum of various improvements regarding the functioning of urban infrastructure and city resources, as well as public services [76,79-84], is increasingly recognized as another distinguishing feature of a smart city. 


\subsection{Typology of Smart City}

Over the years, the concept of a smart city itself has also been gradually evolving. Three generations of it have been distinguished: smart city 1.0, 2.0 and 3.0 by Cohen [85]. The first generation of smart cities, the so-called smart city 1.0 was oriented only to the wide use of modern technologies in cities. These solutions were introduced by companies and the ICT sector which was determined by their potential. In smart city 1.0, citizens were only users of the system, without the right to create solutions.

In the second stage of the development of the concept, i.e., smart city 2.0, the key role was played by local authorities, who decided where to apply modern technologies. In response to the problems diagnosed in the cities, the local authorities were the initiators of their use. The aim of smart city 2.0 was for technologies to improve the quality of life of citizens and their use was to be conscious and selective.

In contrast, smart city 3.0 was based on the active participation of local authorities, technology companies and citizens. In this view, a city could be considered "smart" only when it invested in human and social capital and used smart solutions in all areas, in order to adapt them to the real needs of its inhabitants and, as a result, to increase their quality of life and promote sustainable economic development.

In Cohen's view, the smart city concept will continue to evolve. They may jump, for example, from the 1.0 model straight to the 3.0 model, or they may remain exclusively in the area of one generation.

The smart city of the new era, also called "city of the future" or "green city", is based on the coexistence and cooperation of human individuals and on evolving and constantly adapting to the needs of its inhabitants [86,87]. It is a kind of evolving ecosystem in which it is technological solutions that help dialogue with residents, optimize urban infrastructure and build a high quality of our lives [88].

In the multitude of approaches to the smart city and the lack of a unified concept, the authors of this text have proposed their own definition, which in their opinion best reflects its nature and the very idea of the smart city of the new era. It is a proposal that takes into account all the stages of development of this concept and has a holistic character. In the authors' opinion, smart city should be translated as "the smart city", which is an open, creative and multifunctional space, creating a specific ecosystem based on local authorities, active societies, companies and information and communication technologies, mutually integrated to ensure sustainable development and high quality of life.

\subsection{Smart City Characteristics (Factors)}

As early as 1999, Arun identified what he believed were the key areas that defined the smart city. These were IT education, IT infrastructure, IT economy and quality of life [47]. A similar position was taken by Eger, for whom the key areas of the smart city were: technology, economic development, employment growth and quality of life [89]. On the other hand, in 2007, Giffender noted that a smart city is a city that can do well with six characteristics, which included economy, mobility, environment, people, life and governance, based on independent and informed citizens [41]. In a similar vein, Kourtit, Nijkamp and Arribas, for whom the smart city is based on hu-man capital (skilled workforce), infrastructural capital (intensive and open network connections) and entrepreneurial capital (creative economic activity) [60]. Another researcher, Barrionuevo, distinguished five types of capital that, in his opinion, build the smart city. The basis for him was economic capital understood as GDP, international transactions, foreign and investments. Then he listed people, their talents, creativity, innovation and education. Social capital in turn is tradition, customs, religion and family, while environmental capital is mainly energy, sewage and water policies. As the last, fifth capital, he listed institutionalism, by which he meant civic engagement, administrative authority, and democracy [90].

One of the most extensive studies on smart cities is presented in Mapping Smart Cities in the EU. According to the authors of the report, information and communication technologies (ICT) with the involvement of various stakeholders cooperating with city 
authorities are the key factors that make it possible to "intelligently" build sustainable economic growth in cities and improve the quality of life of their citizens [91]. In their view, a smart city has six main dimensions, which are smart economy, smart mobility, smart environment, smart people and life, and smart governance [17,85,91-93].

The authors of the article, in addition to proposing a new definition of smart city, understood as "smart city", also proposed a set of factors supplemented by a new feature. As a whole, they form the idea of a new generation smart city (Table 1). This compilation also reflects the transformations that have accompanied the development of this concept and illustrates the very process that the smart city has undergone from its inception to the present day. The areas of the modern smart city are thus: Communication/Mobility (Smart mobility), Economy (Smart economy), Governance (Smart governance), Environment (Smart environment), Quality of life (Smart living), People (Smart people), Civil society (Smart civil society).

Currently, depending on their development goals, individual cities around the world are emphasizing different areas from Table 1, with little recognition of the importance of feature seven - smart civil society. Thus, in the United States of America, cities focus on characteristic spatial planning, which assumes the growth of the city in its center while limiting excessive concentration of buildings and people. Other assumptions are made on the European continent, where the greatest attention is paid to the use of information and communication technologies (ICT) in the energy and transport economy. In Australia, on the other hand, the basic smart city is digital media, creative industries and cultural initiatives [94].

At this point, it should be noted that in the opinion of many experts, a smart city is defined as a new technological urban utopia, is expected to become a remedy for all urban problems [78]. However, there is no shortage of voices that express their skepticism about this concept. One of them is presented by Sennett, who warns that a city overly saturated with information will not help people think independently or communicate with each other $[95,96]$.

Table 1. Seven characteristics of the new era smart city.

Feature

1. Smart mobility

\section{Description}

Integrated Transportation System, Integrated transportation and logistics system (including digital), Access to IT

Innovation and Entrepreneurship, Productivity,

Enhancing urban competitiveness, Economic image and trademarks, Flexible labor market, Transformation capacity, International importance

Multi-level city management system (use of e-services, inclusion of civic budget, construction of pro-citizen infrastructure, open data networks),

Local development strategies, Transparency of activities

Climatic conditions,

Environmental protection, Sustainable management of raw materials, Smart buildings,

Environmental awareness, Water consumption, Air quality 
Table 1. Cont.

\begin{tabular}{|c|c|c|}
\hline & Feature & Description \\
\hline 5. & Smart living & $\begin{array}{l}\text { Broad access to public services (access to housing, culture, entertainment), } \\
\text { Personal safety, } \\
\text { Health (life expectancy, quality of health care), } \\
\text { Quality of life, } \\
\text { Education, } \\
\text { Prosperity, } \\
\text { Tourist activity }\end{array}$ \\
\hline 6. & Smart people & $\begin{array}{l}\text { Education, } \\
\text { Qualifications, } \\
\text { Creativity, } \\
\text { Lifelong learning, } \\
\text { Ethnic diversity, } \\
\text { Open-mindedness }\end{array}$ \\
\hline & Smart civil society & $\begin{array}{c}\text { A new social class called the "creative class" } \\
\text { or "new bourgeoisie", } \\
\text { Openness, } \\
\text { Adaptation of new ideas, } \\
\text { Civic engagement, } \\
\text { Democratic }\end{array}$ \\
\hline
\end{tabular}

Own elaboration based on: [17,44,85,97-99].

\subsection{Resilience Approach in Smart City Concept}

Smart cities should also be resilient. The concept of resilience was initially introduced by a well-known ecologist, CS. Holling, who in 1973 suggested two general approaches, i.e., first, man and nature are closely linked and evolve together and must thus be conceived as one social ecology system; second, the responses of this system towards changes are unpredictable, but not proven [21]. After that, the focus is on resilience, then social study [100] and entered the field of planning [101,102]. Understanding the smart city planning concept by incorporating elements of resilience can be reinterpreted to find a new definition. In the context of urban planning, particularly for smart city concepts, the resilient city plays an important role. A city is a complex system, and its resilient capacity needs to be developed; the multi-component capacity, which is the process and interaction that raises it above the city's physical limits. When a city is considered smart it is important to be resilient at any time [22]. Therefore, the concept of resilience is one of the key factors in smart city planning.

As the concept of resilience deepens, it is clear that it allows us to take the first step in adapting to phenomena that may lead to a transformation in the urban ecosystem. This is because the good use of new technologies and communication will allow for the optimization of the quality of life that is offered to citizens. The authors of the article believe that the smart city concept through a resilience approach can be redefined as a concept of a city that utilizes ICT to increase citizens' awareness, intelligence, and wellbeing, as well as community participation. Therefore, it is often seen as a combination of three elements: creativity of people, institutions facilitating knowledge sharing, and information and communication technologies (ICT) that support the creation of innovation [23].

A resilience approach in the smart city is indicated by the concept created by V. Niaros, who, based on two criteria, distinguished four types of smart cities. One of them is the resilient smart city, which follows a philosophy focusing on enabling and empowering citizens for the creation of common value. This bottom-up approach aspires to foster new forms of participatory planning and governance, where social and cultural factors are of significant importance. There are created community-led spaces where individuals meet on a regular basis to engage collaboratively in the creation of meaningful, creative projects [24]. Based on this approach, among others, the authors propose their own model. 


\section{Position of Polish Cities in Smart City Rankings}

The presented smart city characteristics became the basis for the creation of global and European rankings, which are based on selected smart city dimensions. They are measured by means of various criteria, which allow for a subjective assessment of the level of cities' smartization.

\subsection{Ranking Research Methodology}

The growing importance of smart cities is evidenced, among other things, by the growing number of rankings, reports, and academic publications oriented toward urban innovation with a technological edge. There are different methodologies of research and interpretation of "smart cities", from which different groups have been distinguished:

- Ranking of the best local governments of smart cities from a broad list of items that were taken from existing rankings, newspaper articles and websites, based on the developed indicators [27];

- Consideration of a wide range of indicators, falling into several categories, all of which contribute to the final score [26];

- Comparison of the adopted indicators by standardizing the values and standardization. This method converts all indicator values to standardized values with mean 0 and standard deviation. Thus, it takes into account heterogeneity within groups and preserves metric information. In addition, high sensitivity to change is obtained;

- Extracting cities for statistics based on population [25];creation of a standard and a voluntary certification program for the compliance of the measurement of urban service and quality of life indicators with the requirements of this standard [103];

- According the opinions of the residents of each city on the indicated aspects [104].

All of the listed groups have in common the selection of relevant indicators as the basis for the analysis of each ranking (Table 2).

Table 2. Main criteria for evaluating "smart cities" based on selected rankings.

\section{Ranking}

\begin{tabular}{|c|c|}
\hline \multicolumn{2}{|r|}{ Ranking } \\
\hline Criterion & Description/Components \\
\hline \multicolumn{2}{|r|}{ Top 50 Smart City Governments, Eden Strategy Institute } \\
\hline Vision & A clear and well-defined development strategy \\
\hline Leadership & Leadership of a city that implements smart city projects \\
\hline Budget & Sufficient funding for Smart City projects \\
\hline Financial incentives & $\begin{array}{l}\text { Effective encouragement of private sector participation, through grants, rebates, } \\
\text { subsidies, competitions }\end{array}$ \\
\hline Support programs & Programs to encourage private participation (e.g., incubators, events, networks) \\
\hline Talent readiness & Programs that equip the city's talent with smart skills \\
\hline People-centricity & Sincere, people-centric design of the future city \\
\hline Innovation ecosystems & Wide range of stakeholders involved to sustain innovation \\
\hline Smart policies & $\begin{array}{l}\text { Favorable policy environment for smart city development } \\
\text { (e.g., data management, IP protection, urban planning) }\end{array}$ \\
\hline Changes register & Government experience in spurring and accelerating successful smart city initiatives \\
\hline \multicolumn{2}{|c|}{ IESE Cities in Motion Index, IESE Business School, University of Navarra $(2014,2020)$} \\
\hline Human capital & $\begin{array}{l}\text { A city with smart management must be able to attract and retain talent, create plans } \\
\text { for excellence } \\
\text { education and promoting creativity and research }\end{array}$ \\
\hline
\end{tabular}


Table 2. Cont.

\section{Ranking}

\section{Criterion}

\section{Description/Components}

Social cohesion in an urban context refers to the level of coexistence between groups of people living in the same city with different income levels, cultures, ages, and occupations. Understanding a city's social environment requires an analysis of factors such as immigration, community, development, elder care, health system effectiveness, and social inclusion and safety

Economy

Those aspects that promote the economic development of the territory: local economy development plans, transition plans and strategic industrial plans; cluster generation; innovation; and entrepreneurial initiatives

Governance is understood to be strongly correlated with the state of public finances of a city or country. In this sense, public accounts have a decisive impact on the quality of life of the

Governance population and the sustainability of the city, as they determine the level of current and future taxes, the expected growth in the general price level, the opportunities for public investment in basic social infrastructure, and the incentives for private investment

Environmental sustainability through the development of anti-pollution plans, support for

Environment green buildings and alternative energy sources, efficient water and wastewater management, and the existence of policies that support combating the effects of climate change

Mobility and transport

Facilitating travel and access to public services

Include local master plans, green space designs and spaces for public use, prioritizing smart

Urbanism growth and focusing on creating compact, well-connected cities with accessible public services

International coverage

Improve the city's brand and international recognition through strategic tourism plans, attracting investment and foreign representation

Technology

Technology is an aspect of society that improves the current quality of life, and its level of development is an indicator of achieving quality of life

European Smart Cities 4.0, Vienna University of Technology, TUWIEN $(2007,2015)$

\begin{tabular}{|c|c|}
\hline Smart economy & $\begin{array}{l}\text { Spirit of innovation, entrepreneurship, city image, productivity, labor market } \\
\text { international integration }\end{array}$ \\
\hline Smart mobility & Local transport system, ICT infrastructure, sustainability of transport system \\
\hline Smart environment & $\begin{array}{l}\text { Air quality, environmental awareness, } \\
\text { sustainable resource management }\end{array}$ \\
\hline Smart society & Education, lifelong learning, ethnic diversity, open mind \\
\hline Smart life & $\begin{array}{l}\text { Cultural and recreational facilities, health conditions, safety, quality of housing, educational } \\
\text { facilities, tourist attractiveness, social cohesion }\end{array}$ \\
\hline Smart management & $\begin{array}{l}\text { Political awareness, access to public and social services, efficient and } \\
\text { transparent administration }\end{array}$ \\
\hline \multicolumn{2}{|r|}{ Polish Committee for Standardization, ISO PN-ISO 37120:2015-03 } \\
\hline Economy & $\begin{array}{l}\text { Unemployment, commercial and industrial real estate, percentage of population living in } \\
\text { poverty, employment, number of businesses }\end{array}$ \\
\hline Education & $\begin{array}{c}\text { Percentage of population to a given education by gender, student to teacher ratio, number } \\
\text { of degrees in higher education }\end{array}$ \\
\hline Energy & Energy consumption, including renewable energy \\
\hline Environment & Gas emissions, noise \\
\hline Finance & Debt, expenses, income, taxes \\
\hline
\end{tabular}

Fire and Emergency Services

Number of firefighters, number of deaths from fires or emergencies, emergency services response time 
Table 2. Cont.

\begin{tabular}{cc}
\hline Criterion & Ranking \\
\hline Administration & Description/Components \\
\hline Health & Life expectancy, number of hospital beds, number of medical staff, suicide rate \\
\hline Recreation & Recreational space area \\
\hline Security & Number of officers, crimes, police response time from receiving a call \\
\hline Shelters & Percentage of homeless and living in slums \\
\hline Solid Waste & Amount of solid waste \\
\hline Telecommunications and innovation & Public transportation system, annual number of travelers, passenger cars, commercial \\
\hline Transport & air service \\
\hline Spatial planning & Acreen areas, number of trees planted, jobs to housing ratio \\
\hline Sewage & Access to drinking water, water consumption \\
\hline Water and sanitation & Own elaboration based on: $[25-27,98,103]$.
\end{tabular}

The criteria listed in Table 2 constitute only the name of the set with detailed indicators. Among the most important groups of criteria, common to all rankings, determining the level of a city's "intelligence" we can distinguish elements related to economy, management, human capital, innovation, transport, political system and urban planning.

\subsection{Implications for Polish Cities}

In the above rankings, there is also a place for Polish cities (see Table 3). In the IESE Cities in Motion Index 2020 report, such cities as Warsaw and Wrocław are, respectively, ranked 54th and 88th out of 174 cities worldwide. It is worth emphasizing that in the criterion related to management, Warsaw is in the Top 10, remaining in the 8th position. In addition, Wrocław is in second place among the five highest-scoring cities in Eastern Europe. In the case of Warsaw, there was a promotion from the position 76th in 2014, while Wrocław decreased its position by 6 places, highlighting that in 2014 the ranking included 135 cities from all over the world [26].

The 2015 European Smart Cities 4.0 ranking recognized as "smart" the following cities: Bydgoszcz, Gdańsk, Katowice, Kraków, Łódź, Lublin, Poznań, Szczecin, Wrocław. However, it should be emphasized that the ranking only covers European cities with a population between 300 thousand and 1 million, which significantly narrows the statistics. In the previous edition, in 2007, the ranking included the following Polish cities: Rzeszów (48th place), Białystok (53rd place), Bydgoszcz (57th place), Szczecin (62nd place), Kielce (64th place) [25].

An ISO standard PN-ISO 37120:2015-03 was created within the Polish Committee for Standardization, which has so far been met by one Polish city, Lublin, for the period 2019-2022 [103].

In the Smart City Index 2021, there are two Polish cities-Warsaw (75th place) and Krakow (80th place). This ranking registers the opinions of 120 citizens from 118 cities around the world. There are two pillars to which residents' attention is drawn: the pillar relating to the existing infrastructure of the cities, and the technological pillar describing technological solutions and services available to residents. In turn, each is evaluated in five key areas: health and safety, mobility, operations, opportunities, and governance [104]. 
Table 3. Positions of Polish cities in Smart City rankings.

\begin{tabular}{|c|c|c|c|c|}
\hline Ranking & Year & Global, European, National & Positions of Polish Cities & \\
\hline $\begin{array}{l}\text { Top } 50 \text { Smart City Governments, Eden } \\
\text { Strategy Institute }\end{array}$ & $2020 / 2021$ & global & no & no \\
\hline IESE Cities in Motion Index & 2020 & global & $\begin{array}{l}\text { Warsaw (54th place), } \\
\text { Wrocław (88th place) }\end{array}$ & $\begin{array}{l}\text { The cities are grouped according to their perfor-mance, measured by the value of the } \\
\text { synthetic indicator within } 9 \text { dimensions (Economy, Human capital, Social cohesion, } \\
\text { Environment, Governance, Urban planning, International projection, Technology, Mobility } \\
\text { and transportation) } \\
\text { Warsaw- } \\
\text { (8th place in dimension Governance, 14th place in Urban planning, 47th place in Social } \\
\text { cohesion and Mobility and transportation) } \\
\text { Wroctaw } \\
\text { (27th place in Mobility and transportation, 56th place in Urban planning, 60th place in } \\
\text { Social cohesion) }\end{array}$ \\
\hline $\begin{array}{l}\text { European Smart Cities } 3.0 \\
\text { European medium-sized cities (cities from } \\
100,000 \text { to } 500,000 \text { inhabitants) }\end{array}$ & 2013 & European & $\begin{array}{l}\text { Rzeszów (55th place), Szczecin (56th place), } \\
\text { Bydgoszcz (62nd place), Białystok (66th } \\
\text { place), Kielce ( } 68 \text { th place) } \\
\text { Suwałki (70th place) }\end{array}$ & $\begin{array}{c}\text { Evaluation of the city based on the criteria: Smart Economy, Smart People, Smart } \\
\text { Governance, Smart Mobility, Smart Environment, Smart Living. } \\
\text { Rzeszów (49th place for Smart Governance criterion, 50th place for Smart Living) } \\
\text { Szczecin (50th place for Smart Governance criterion, 55nd place for Smart Mobility) } \\
\text { Bygdoszcz (50th place for Smart Mobility criterion, 54th place for Smart Governance, 60th } \\
\text { place for Smart Economy) } \\
\text { Białtystok (45th place for Smart Governance criterion, 61th place for Smart Mobility and } \\
\text { Smart Living) } \\
\text { Kielce (51th place for Smart Governance criterion, 58nd place for Smart Living) } \\
\text { Suwałki (55th place for Smart Governance, 57nd place for Smart Mobility) }\end{array}$ \\
\hline $\begin{array}{c}\text { European Smart Cities } 4.0 \\
\text { Larger European cities (cities from } 300,000 \text { to } \\
1 \text { million inhabitants) }\end{array}$ & 2015 & European & $\begin{array}{l}\text { Bydgoszcz, Gdansk, Katowice, Krakow, Lodz, } \\
\text { Lublin, Poznan, Szczecin, Wroclaw }\end{array}$ & $\begin{array}{c}\text { Evaluation of the city based on the criteria: Smart Economy, Smart People, Smart } \\
\text { Governance, Smart Mobility, Smart Environment, Smart Living. } \\
\text { Best rating key fields: } \\
\text { Krakow (Smart Living, Smart Mobility) } \\
\text { Wrocław (Smart Environment, Smart Living) } \\
\text { Bydgoszcz (Smart Environment) } \\
\text { Gdańsk (Smart Environment) } \\
\text { Katowice (Smart Environment) } \\
\text { Łoznan (Smart Living), Sczecin (Smart Environment) } \\
\text { Łódzublin (lack of data) }\end{array}$ \\
\hline $\begin{array}{l}\text { Polish Committee for Standardization, ISO } \\
\text { PN-ISO 37120:2015-03 }\end{array}$ & 2019 & national & Lublin & $\begin{array}{c}\text { Certificate of management of city services and quality of life (meeting standards based on } 96 \\
\text { indicators for stimulating metropolitan development and strategic planning) }\end{array}$ \\
\hline Smart City Index & 2021 & global & Warsaw (75th place), Cracow (80th place) & $\begin{array}{l}\text { Provisions of the city across five key areas: health and safety, mobility, activities, } \\
\text { opportunities and governance. } \\
\text { Cities are assigned a rating scale (AAA-AA-A to D) based on the perceptions-score of a given } \\
\text { city compared to the scores of all other cities within the same group). } \\
\text { Warsaw } \\
\text { (Smart City Rating-CCC, Structure-CCC, Technology-CCC) } \\
\text { Cracow } \\
\text { (Smart City Rating-CCC, Structure-CCC, Technology-CCC) }\end{array}$ \\
\hline
\end{tabular}


It can be concluded that over the years, in the pursuit to combine economic growth with environmental improvement and a more positive image, Polish cities have started to adopt Smart City strategies. This study identifies areas of success of that process in Polish cities in relation to global and European rankings. The study included a content analysis of official documents, reports, rankings and websites profiling Smart City strategies. This analysis made it possible to identify the main methods of creating studies (detailed criteria), which are the basis for assessing the "intelligence" of the city and to indicate the position of Polish cities in selected rankings. It becomes visible that Polish cities are on their way to becoming leaders and initiators of changes. However, current smart strategies of Polish cities are rather a response to commonly prevailing trends, rankings, competitions in which it is possible to obtain an appropriate number of points or an appropriate amount of financing for some selected smart solution. Polish urban policy is too narrowly focused on infrastructure and spatial resource management, often treating smart solutions as a city's business model. There is also a lack of a smart city management culture. City managers' knowledge and often their skills are also insufficient. To enable smart city initiatives, this category should also include integrated and transparent smart management through strategic and promotional activities, not just administrative ones [92]. Networks and partnerships of all city stakeholders must be established. At every level, smart administration means being fully citizen-centered. Institutional readiness is important here. According to the European smart city direction, managers should create the right environment for the emergence and/or development of creative specialties, in real terms and not only on paper, e.g., by removing legal and regulatory barriers or changes in the vision of the city.

The presented barriers in the process of smartization of Polish cities are only selected, the most important characteristics of the strategies of the cities. There are many necessary changes to be implemented. In order to design those changes, cities in Poland need a model which will show them the direction of those changes and enable them to advance the process of city smartening. Attempts to create such patterns are reflected in various models of smart city management functioning in the world.

\section{Results of Smart City Model Analysis}

The smart city models proposed so far are more or less complex. However, they indicate the variety of areas of cities that need to cooperate in order for a given city to find its place in a chosen ranking (local, global) or to realize its strategy. These models indicate specific elements of a smart city at many levels of detail, i.e., they describe all actors (stakeholders) involved, their relationships, activities, as well as indicators to be monitored. They are the basis for developing 'smart' projects.

\subsection{Analysis of Functioning Smart Cities' Models}

One of the first and most popular Smart City Model concepts is the one proposed by Griffinger which is the basis for later models [18]. It is a classification system in which smart cities are developed in six different directions. It was developed as a tool for ranking European medium-sized cities in terms of six dimensions of "smart" cities: economycompetitiveness (Smart Economy), people-human and social capital (Smart People), environment-natural resources (Smart Environment), mobility—transport and ICT (Smart Mobility), governance-participation (Smart Governance), quality of life (Smart Living). The city, according to this model, should also provide high usability to its inhabitants by analyzing the current state of the city with the help of specifically selected 74 indicators (Figure 1). The model seems to be so comprehensive that individual cities can use the tool to create their own goals, however, suggesting the features defined by the model [81]. 


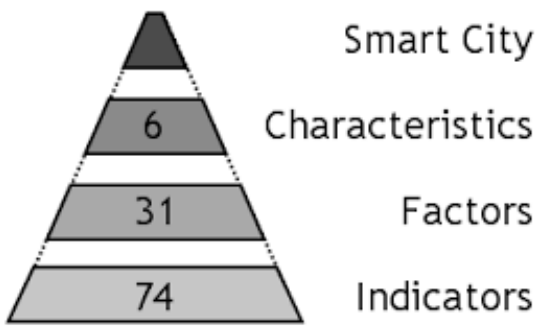

Figure 1. Description of smart cities. Source: Griffinger, R. [93].

Another model was proposed by Cohen [105]. The Smart Cities Wheel model identifies six key dimensions (smart economy, smart environment, smart governance, smart living, smart mobility and smart people), which can also be seen as the six key components that make up a smart city. Three key drivers are introduced for each of these components, while over 100 indicators help cities track their performance (Figure 2).

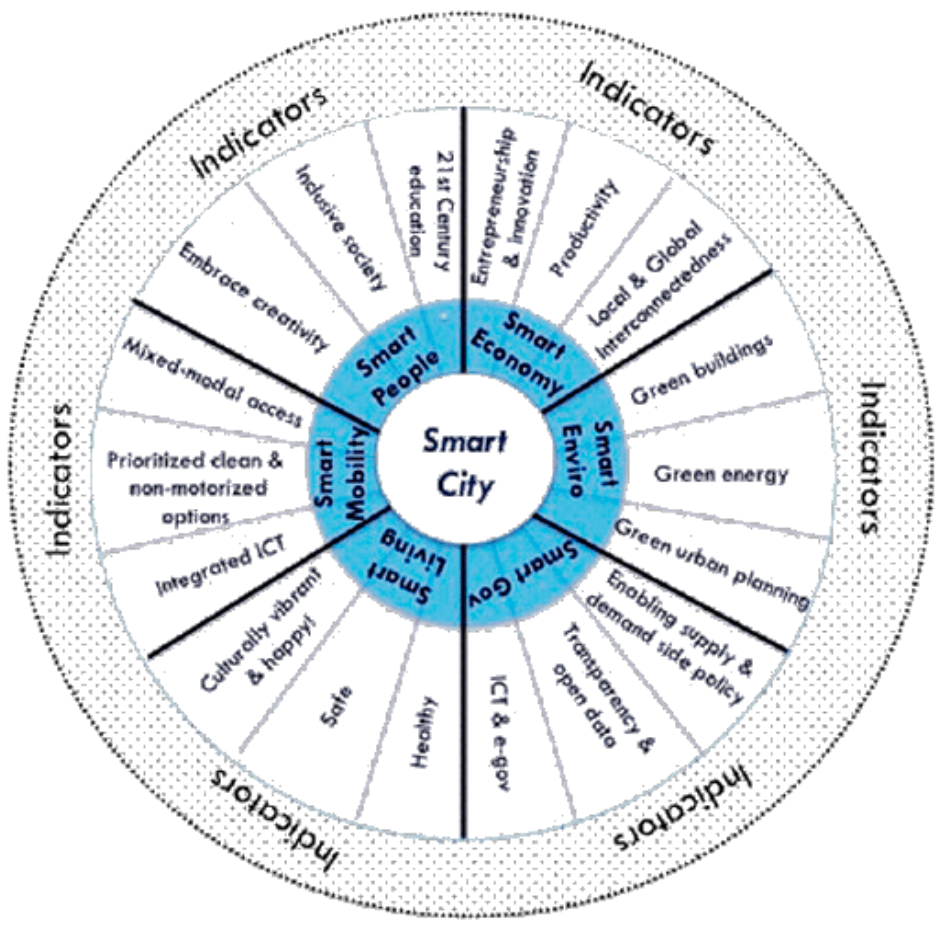

Figure 2. Smart Cities Wheel Model proposed by B. Cohen. Source: Cohen B. [97].

The components of this model are identical to the model proposed by Griffinger discussed earlier. However, Cohen's model distinguishes different factors for each of the components that affect the functioning of the city. Cohen proposes several steps for building the model [16]. First, a vision for the city should be defined with the involvement of its inhabitants. In pursuing the established vision, cities should first develop a baseline or measurement that can be used as a starting point before setting numerical targets. They can then set target indicators. Cities need to develop their own benchmarks and target indicators based on their own needs and existing capabilities while following the best practices of leading smart cities around the world. The needs and challenges arising from population density, topography and existing infrastructure vary greatly from city to city, so defining their own vision for the city and how to move towards achieving that vision themselves can be seen as defining their own vision for the city and how to achieve it can be seen as essential in any attempt to develop a smart city model that is applicable to a city of any scale. Another important guideline proposed by Cohen is to 'go lean'. Cities should 
follow lean start-up principles. They should identify goals that can be easily achieved while building long-term action plans.

Due to its popularity, one of the concepts selected in this article isthe Smart Cities Maturity Model, developed by the Scottish Cities Alliance (Figure 3) [106].



Figure 3. Smart Cities Maturity Model. Source: [106].

The smart city maturity model presented above considers maturity in five dimensions. Smart cities: have a strategy that identifies what investments in data and digital technologies enable service reform and collaboration with partners, and focuses on achieving better outcomes aligned with the city's strategic priorities; make effective use of their data assets that underpin their commitment to innovation; invest in open, flexible, integrated and ICT processes that enable innovation in providing automated and dynamic real-time response capabilities; adapt traditional organizational delivery models to take advantage of digital opportunities; make the best use of data and digital technologies to engage stakeholders, be proactive in supporting the digitally excluded.

Another perspective is the commercial (smart city) models of the leading leaders in the provision of smart solutions worldwide: the IBI and Hitachi. In the IBI model, we can distinguish three pillars: people, infrastructure, activities. Accordingly, three basic services have been identified, namely: services for people (education, healthcare, social programs), infrastructure services (energy, water, transport) and urban planning and management services (public safety, urban planning, resource management). This approach focuses on the application of new IBM solutions to many aspects of the city but lacks consideration of explicit dependencies (relationships) between the different elements $[20,107]$. In a very similar way, Hitachi defines the concept of a smart city, i.e., consisting of three layers: infrastructure, urban services and urban lifestyle, in which advanced information technologies are used to improve energy efficiency and care for the global environment [19]. These are typically commercial models, focused on the use of technology in the management of cities and its inanimate elements.

Each of the above concepts has its advantages but does not create a comprehensive solution for cities. Moreover, the authors of these models suggest developing their own indicators for individual cities, which makes it impossible to compare cities with each other and thus determine which of them is more developed towards smartness. Commercial models mainly focus on the use of information and communication technologies. These solutions present innovative ways of city management through, for example, smart buildings, intelligent traffic management, more efficient energy consumption or more efficient waste management.

\subsection{Smart City Model Proposal for Polish Cities}

Most available models and rankings of selected Polish cities created on their basis focus on certain characteristics of an intelligent city, such as constant development of areas of city functioning, using innovative technologies to increase the effectiveness and quality of activities and real-time data collection and analysis. These concepts do not treat the city holistically, but only single out specific elements of the city, omitting the essence of the relationship between them, especially their users. Information and communication technologies are number one and the emphasis is on the possibilities of using them in 
each area of city functioning, while city dwellers are often treated as uninvolved recipients, consumers of products and services offered by the city.

The COVID-19 crisis clearly demonstrated that cities suffer if their citizens suffer and that without the welfare of the latter, they are just empty structures. Their design should therefore focus on the quality of life. To achieve this, it is necessary to promote a policy of social development, and this in turn will be the key to achieving economic recovery. In this sense, cities should put special emphasis on the joint development of the social and economic cohesion dimension. Therefore, the authors of the article propose a model for Polish cities aimed at activating and motivating their inhabitants to create and develop the city. A stronger relational approach to city management is necessary. Relationships are rooted in local conditions shaped by formal institutions and in the system of values, the motivation to cooperate and the trust of inhabitants. These forces are equivalent. Consequently, for the development of a smart city, the results of taking these elements into account are manifested in the faster and cheaper acquisition of information from the inhabitants that is more reliable. This facilitates the introduction of smart solutions into the space, improving the quality of life of the inhabitants (health, safety, education) and building trust between the actors of the local system, reducing disruptions and communication conflicts between them.

A participatory approach in managing smart cities was proposed by Niaros [24]. The authors of the article, inspired by this taxonomy, propose a smart city model for polish cities, however, focused on the resilience paradigm, understood as the resilience of the city, built on community and shared values, with emphasis on the local scale and with the participation of citizens in the process of designing and implementing physical (technological) and humanistic infrastructure. Important features of this approach are: bottom-up initiatives of citizens, creating conditions for the involvement of the local community in the processes of co-creation of smart solutions, creating space for the creation of an urban environment of open innovation and technology based on open access, defining local values and needs of the city as a result of cooperation between the local administration and citizens (See Figure 4). Such community-developed projects are extremely important for society as a whole because they promote social solidarity, i.e., sharing and cooperation [108].

The necessary conditions of the proposed model (Figure 4) were constructed on the basis of the specificity of Polish cities and the assumptions of the European approach to the development of the smart city model, which are regulated by the documents mentioned in part 2.1 of this article. In most Polish cities there is a lack of long-term experience in applying strong and sophisticated planning tools [109].

In line with these assumptions, Gontar [12] enumerates potentials, but also significant technological and financial ones facing Polish cities in the development of such smart projects.

Based on the information from the rankings cited in Part 3 of this article, it can be concluded that the smart strategies applied in Polish cities are still administrative in nature, especially with regard to e-government and e-services, and the conservative management style and poor transparency of governance thwart progress in achieving greater citizen involvement.

In the model presented here, a specific city is at the center, with its own mission, vision, priorities and planning for that specific city. Polish cities often understand smart cities as a strategy for solving economic and/or political problems at the same time, thus creating a gap between smart city ambitions and actual city management practices.

The proposed model includes three components, which are the pillars of a smart city, which contain specific factors and have their specific functions defined, through which the relationships between it and the smart city and its actors are formed. These are: technological component, human component, institutional component, in which specific solutions can be applied. 


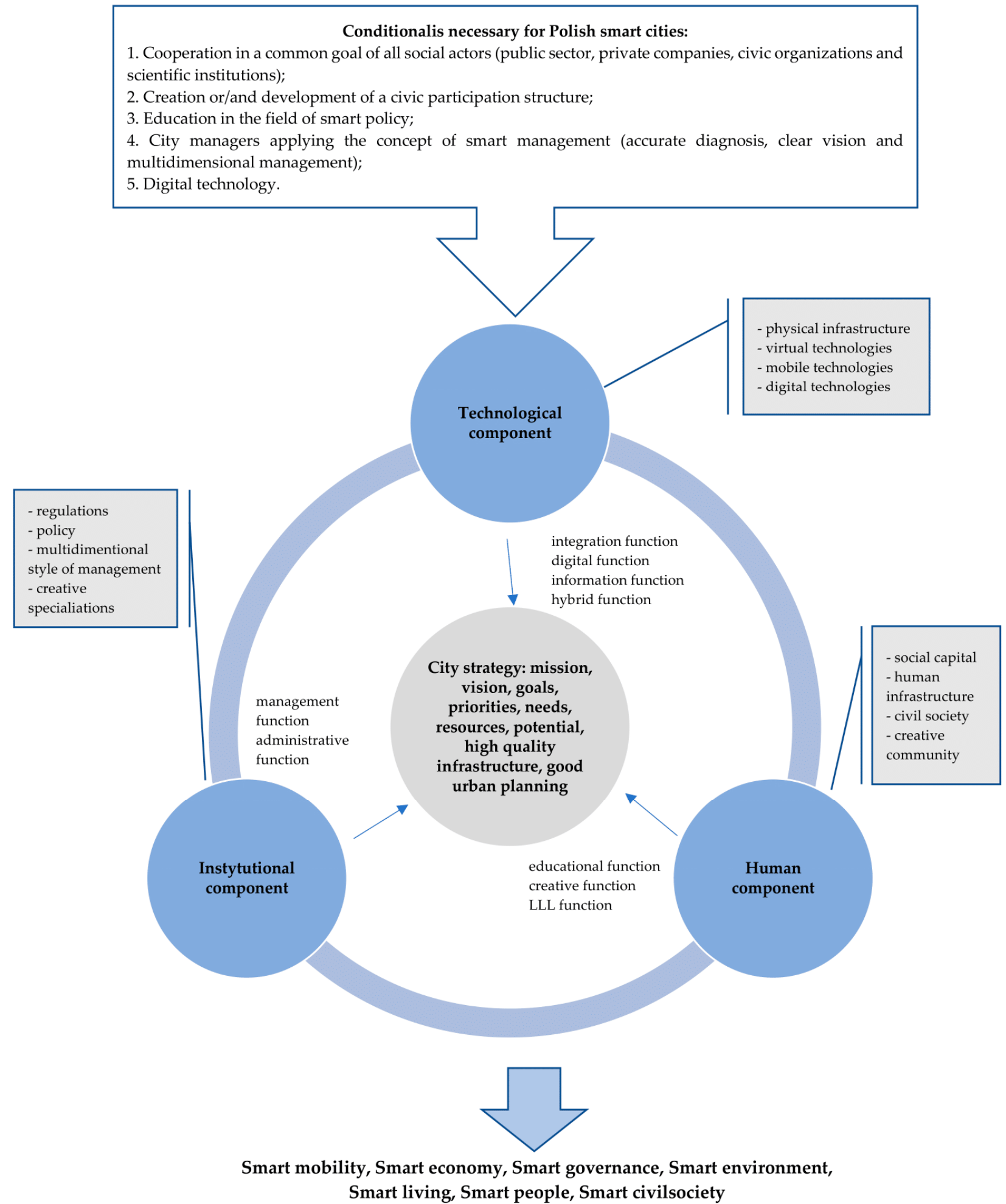

Figure 4. The resilient smart city model. Source: own elaboration.

Most of the models described earlier, especially the commercial models of IBI and Hitachi, emphasize technological issues. The model presented here focuses on social aspects, the so-called "soft" ones, which are often difficult to grasp, but which have a major impact on the current smart city model, namely creativity, innovation and social involvement (mainly of the inhabitants). According to experts, they are the ones that have the greatest in- 
fluence on the modernist vision of an ideal city, based on individualism, attracting creative, skilled and entrepreneurial people, forming the so-called creative class [72,110,111].

An obvious component of the resilient smart city model is digital technology, as it must be part of any new age smart city, in order to improve quality in social, economic and technological dimensions. However, it is meant to be a tool for the implementation of smart city strategies, as the basis of the "cities of the future", however, is the way they are organized, and the strategies of these cities should start with people and not with technology $[13,112,113]$. A well-functioning information and communication technology (ICT) infrastructure, in addition to its digital-networking functions, has an integration and information function for public institutions, the private sector, social organizations and citizens.

These technologies offer city dwellers the benefits of a mobile lifestyle. The smart city application is evolving from smart places to networked citizens [114].

The Human component is the most important component of the author's model. First of all, it includes investments in human and social capital, as well as in communication infrastructure, which aims to promote sustainable economic development and high quality of life, including sound management of natural resources, through citizen participation [49]. This area includes various factors such as a propensity for lifelong learning, smart education, creativity. Problems related to urban agglomerations can be solved through creativity and cooperation between stakeholders (including citizens) and their "smart solutions". A creative community (civil society): participates in providing data on the functioning of the urban infrastructure, uses ICT to improve the quality of life, supports (but also controls) city authorities in the process of city management, helps other inhabitants in the learning process, creates a climate of a creative, learning city.

Collective intelligence and social learning make the city smarter [115].

The decisive factor for the success of any city is its inhabitants and their interaction and services that are accessible to all, without barriers of language, culture, age, education.

The third, Institutional component includes factors such as: regulations, policy, multidimensional style of management, creative specializations. This is mainly due to the fact that management support is fundamental for the design and implementation of smart cities. Currently, Polish cities do not apply a comprehensive, decentralized approach to planning, implementation of "tailor-made" smart cities. The role of the government in this process is important; it sets the relevant policies, the guidelines that cities must or want to follow to be competitive.

City authorities should share smart city concepts, visions, goals, priorities and even strategic plans of a smart city with the public and stakeholders [116]. Smart managers are needed because the leadership of key leaders and their strong support for the smart city vision are fundamental to its success [117]. Besides, a new strategy must be created for the new COVID-19 environment (including measures of social distance; space for traditional trade to compete with growing e-commerce; public transport needs to ensure minimum distances between passengers; and interactions between citizens in green spaces may change periodically).

The model is crowned with the author's definition of a new generation smart city, consisting of seven features, which is described in detail in Table 1.

The proposed author's model emphasizes the essence of the relational approach between the individual elements of the model, its factors and smart city actors. This approach gives a chance to create a creative community, which will be involved in the creation of a smart city, according to local needs and priorities and the level of development of the city.

\section{Discussion and Conclusions}

The smart city concept is a relatively new, very capacious concept, which includes many features of modern cities. It is a concept that is changing and will continue to change under the influence of challenges arising from the environment, highlighting aspects 
that are important for the city and its managers. All analyzed concepts of smart city management have their advantages and disadvantages and, first of all, show the priorities in city management and indicate the areas of current and potential investments. However, they do not create a comprehensive development model for cities, forgetting about the specificity of their location, economic, social and cultural features. Moreover, city managers measure smart city characteristics in different ways, with different levels of detail. This situation makes it impossible to objectively compare cities and the degree to which they meet the smart city classification criteria, and to objectively assess the level of a city's involvement in the smartification process.

Polish cities have ambitions to become smart. However, as the rankings presented in the article show, there are not many such cities, and they occupy very distant positions in those rankings. In order to show the way of development to Polish cities, a model based on the existing concepts and ranking analyses was proposed. However, the model takes into account the specificity of Polish cities as well as current issues which must appear in management models, such as the paradigm of the city's resilience and the existing pandemic which permanently inscribes itself in the life of societies and changes existing solutions and priorities.

The model was proposed thanks to the realization of particular detailed objectives. Their levels and the resulting conclusions are presented in the following paragraphs.

1. Based on the systematic literature review, the existing smart city concepts were presented and evaluated. The most important smart city features presented in the literature were pointed out as well as a new area that should appear in the smart city characteristicssmart people. This made it possible to propose a new, holistic definition of smart city for polish cities, taking into account the specificity of the country and the challenges of the 21st century, and seventh feature that makes up a smart city of the new era-smart civic society - often overlooked in the discourse on the model, characterized by the need to build a new social class, called "creative class", the need to adapt new ideas, openness, civic engagement and democracy.

2. Based on a systematic literature review, a presentation of existing smart city models used in city management was made. The article presents the most popular models. Their different dimensions and ways of measuring them were also presented. Thanks to this, on the basis of a comparison of the models, dimensions that are repeated were identified, indicating their priority, as well as dimensions that are different due to the specificity of the city, its location or level of development. Additionally, existing approaches to resilient smart city were analyzed. The characteristics of a resilient smart city created by V. Niaros were used in the final model.

3. On the basis of the analysis of rankings and formal documents, Polish cities that fit into the smart city concept were identified. The positions of Polish cities were determined and the areas that those cities have the most developed were identified, showing the level of implementation of the smart city concept. Polish cities appear in distant positions in the rankings. This indicates that they are at an initial stage in the smart city concept. Additionally, the analysis of formal documents allowed to determine the specificity of Polish cities, which was included in the preliminary conditions of the final model called as a "Necessary conditions for Polish smart cities".

The activities within the scope of items 1-3 allowed for proposing the author's model of resilient smart city for Polish cities. Therefore, in the proposed model, including elements important for all smart city concepts, there appeared features that respond to current challenges, on which the authors of the article put special emphasis. These are the so-called "soft" issues of the model which relate to society, build relationships and improve the well-being of societies as well as stimulate creativity and innovation. The model presents an approach based on involving citizens in the management processes of the city, creating conditions for the involvement of the local community in the processes of co-creating smart solutions and spaces for creating an urban environment. Social involvement becomes the basis for creating open innovation or responsible innovation resulting from the cooperation 
of many diverse stakeholders. The model also emphasizes the need to recognize the local values and needs of a given city and the solutions created should be tailored to local needs. Therefore, it emphasizes the partnership of all the city's stakeholders. In the opinion of experts, it is they who have the greatest influence on the development of the smart city. The groups of factors proposed in the model indicate the conditions that need to be met in order to become a smart city, the so-called necessary conditions, the complementary conditions that make the city take care of the social well-being and the conditions that are specific to the city and will indicate the areas in which the city can and wants to invest, which are important for its development towards smartness, and which result from the existing strategies.

The authors are aware of the fact that the proposed model is not empirically verified, however, it may constitute a description of an ideal state, the task of which is to determine the way of development. Moreover, it is worth striving for the creation of assessment and evaluation tools/criteria that would allow for an objective measurement of the degree of smart cities, which may constitute a research challenge for the future.

The added value of the article is also that the authors propose a new, unambiguous and holistic definition of smart city for Poland, taking into account the specificity of the country and the challenges of the 21st century. There is also the seventh feature added that makes up the smart city of the new era-smart civil society-often overlooked in the discourse on the model, characterized by the need to build a new social class, called "creative class", the need to adapt new ideas, openness, civic involvement and democracy.

Author Contributions: Conceptualization, M.B., M.K., M.C. and K.M.-P.; methodology, M.B. and M.K.; formal analysis, M.B., M.K., M.C. and K.M.-P.; investigation, M.B. and M.K., resources, M.C. and K.M.-P.; writing—original draft preparation, M.B., M.K., M.C. and K.M.-P.; writing—review and editing, M.B., M.K., M.C. and K.M.-P.; visualization, M.C. and K.M.-P. All authors have read and agreed to the published version of the manuscript.

Funding: This research received no external funding.

Conflicts of Interest: The authors declare no conflict of interest.

\section{References}

1. Grzebyk, M.; Stec, M. Sustainable Development in EU Countries: Concept and Rating of Levels of Development. Sustain. Dev. 2015, 23, 110-123. Available online: https:/ / onlinelibrary.wiley.com/doi/10.1002/sd.1577 (accessed on 30 December 2021).

2. Krajnc, D.; Glavic, P. A Model for Integrated Assessment of Sustainable Development. Resour. Conserv. Recycl. 2005, 43, 189-208. Available online: https://www.sciencedirect.com/science/article/abs/pii/S092134490400120X?via\%3Dihub (accessed on 19 December 2021). [CrossRef]

3. Ball, A.; Bebbington, J. Accounting and Reporting for Sustainable Development in Public Service Organizations. Public Money Manag. 2010, 28, 323-326. [CrossRef]

4. Di Fabio, A.; Palazzeschi, L.; Bucci, O.; Guazzini, A.; Burgassi, C.; Pesce, E. Personality Traits and Positive Resources of Workers for Sustainable Development: Is Emotional Intelligence a Mediator for Optimism and Hope? Sustainability 2018, 10, 3422. [CrossRef]

5. Yigitcanlar, T. Smart cities: An effective urban developmentwsazuje and management model? Aust. Plan. 2015, 52, 27-34. [CrossRef]

6. Yigitcanlar, T.; Dur, D.; Dizdaroglu, D. Towards prosperous sustainable cities: A multiscalar urban sustainability assessment approach. Habitat Int. 2015, 45, 36-46. Available online: https://eprints.qut.edu.au/74725/2/74725.pdf (accessed on 19 December 2021). [CrossRef]

7. Angelidou, M. Smart cities: A conjuncture of four forces. Cities 2015, 47, 95-106. [CrossRef]

8. Angelidou, M. Smart city policies: A spatial approach. Cities 2014, 41, 3-11. [CrossRef]

9. Joss, S. Eco-cities and Sustainable Urbanism. In International Encyclopedia of the Social E Behavioral Sciences, 2nd ed.; Wright, J.D., Ed.; Oxford Elsevier: Oxford, UK, 2015; Volume 6, pp. 829-837.

10. Trinidade, E.P.; Hinning, M.P.F.; Da Costa, E.M.; Marques, J.S.; Bastos, R.C.; Yigitcanlar, T. Sustainable development of smart cities: A systematic review of the literature. J. Open Innov. Technol. Mark. Complex. 2017, 3, 11. Available online: https: //jopeninnovation.springeropen.com/articles/10.1186/s40852-017-0063-2 (accessed on 19 December 2021). [CrossRef]

11. Carrillo, F.J. Capital Cities: A Taxonomy of Capital Accounts for Knowledge Cities. J. Knowl. Manag. 2004, 8, 28-46. [CrossRef]

12. Gontar, Z.; Gintar, Z.; Pamuła, B. Deployment of Smart City Concepts in Poland. Selected Aspects. Organizaciju Vadyba: Sisteminiai Tyrimai, No. 67. 2013, pp. 39-51. Available online: https://www.vdu.lt/cris/bitstream/20.500.12259/963/1/ISSN2 335-8750_2013_N_67.PG_39-51.pdf (accessed on 19 November 2021). 
13. Caragliu, A.; Del Bo, C.; Nijkamp, P. Smart Cities in Europe. J. Urban Technol. 2011, 18, 65-82. Available online: https: / / www.tandfonline.com/doi/abs/10.1080/10630732.2011.601117 (accessed on 15 December 2021). [CrossRef]

14. Jong, M.; Joss, S.; Schraven, D.; Zhan, C.; Weijnen, M. Sustainable-smart-resilient-low carbon-eco-knowledge cities; making sense of a multitude of concepts promoting sustainable urbanization. J. Clean. Prod. 2015, 109, 25-38. [CrossRef]

15. Lee, J.H.; Gong Hancock, M.; Hu, M.C. Towards an Effective Framework for Building Smart Cities: Lessons from Seoul and San Francisco. Technol. Forecast. Soc. Chang. 2014, 89, 80-99. Available online: https://ur.booksc.eu/book/23020055/ea5f37 (accessed on 19 December 2021). [CrossRef]

16. Cohen, B. The Smartest Cities in the World 2015: Methodology. Available online: https://www.fastcompany.com/3038818/thesmartest-cities-in-the-world-2015-methodology (accessed on 30 November 2021).

17. Cohen, B. The Top 10 Smartest European Cities. 2015. Available online: https://www.fastcompany.com/3024721/the-10 -smartest-cities-in-europe (accessed on 20 November 2021).

18. Griffinger, R.; Haindlmaier, G. Smart Cities ranking: An effective instrument for the positioning of cities? ACE, Catalonia, Centre de Política del Sòl i Valoracions-Universitat Politècnica de Catalunya. Int. Encycl. Soc. Behav. Sci. 2009, 12, 14-15. Available online: https://upcommons.upc.edu/bitstream/handle/2099/8550/ACE_12_SA_10.pdf?sequence=7\&isAllowed=y (accessed on 14 December 2021).

19. Hitachi Sustainability. Available online: https://sustainability.hitachi.com/ (accessed on 14 December 2021).

20. IBM. Available online: https://www.ibm.com/smarterplanet/us/en/smarter_cities/solutions/human_solutions / (accessed on 19 December 2021).

21. Holling, C.S. Resilience and Stability of Ecological Systems. Annu. Rev. Ecol. Syst. 1973, 4, 1-23. [CrossRef]

22. Desouza, K.C.; Flanery, T.H. Designing, planning, and managing resilient cities: A conceptual framework. Cities 2013, 35, 89-99. [CrossRef]

23. Komninos, N. The Age of Intelligent Cities. Smart Environments and Innovation-for-All Strategies; Routledge Taylor\&Francis Group: New York, NY, USA, 2015; p. 82.

24. Niaros, V. Introducing a Taxonomy of the "Smart City" Towards a Commons Oriented Approach? Triplec Commun. Capital. Crit. J. Glob. Sustain. Inf. Soc. 2016, 14, 56-57.

25. European Smart Cities 4.0, Vienna Univertisty of Technology, TUWIEN. 2015. Available online: http:/ / www.smart-cities.eu/ ?cid=2\&ver=4 (accessed on 15 December 2021).

26. IESE Cities in Motion Index; IESE Business School, University of Navarra: Navarra, Spain, 2020.

27. Top 50 Smart City Governments; Eden Strategy Institute: Singapore, 2021.

28. Czakon, W. Metodyka systematycznego przeglądu literatury. Przegląd Organ. 2011, 3, 57-61. [CrossRef]

29. Gotlibowska, K. Propozycja modelu miasta inteligentnego (Smart city) opartego na zastosowaniu technologii informacyjnokomunikacyjnych w jego rozwoju. Rozw. Reg. Polityka Reg. 2018, 42, 67-80.

30. Hajduk, S. Bibliometric Analysis of the Concept of the Smart City in International Scientific Literature; Internal TradeNo. 3(368); Instytut Badań Rynku, Konsumocji i Koniunktury: Warszawa, Poland, 2017; pp. 301-312.

31. Harrison, C.; Donnelly, I.A. A Theory of Smart Cities. In Proceedings of the 55th Annual Meeting of theISSS, Hull, UK, 17-22 July 2011; Curran Associates Inc.: Red Hook, NY, USA; pp. 521-535. Available online: http://journals.isss.org/index.php/ proceedings55th/article/viewFile/1703/572 (accessed on 21 December 2021).

32. Klepka, M. Model Smart City i Jego Związek z Rozwojem Przedsiębiorstw, Przedsiębiorczość i Zarządzanie, 2019/20/8. Available online: http:/ / piz.san.edu.pl/docs/e-XX-8.pdf (accessed on 19 December 2021).

33. Larsen, E.M.; Pinson, P.; Leimgruber, F.; Judex, F. Demand response evaluation and forecasting-Methods and results from the EcoGridEU experiment. Sustain. Energy Grids Netw. 2017, 10, 75-83. [CrossRef]

34. Masik, G.; Sagan, I.; Scott, J.W. Smart City strategies and new urban development policies in the Polish context. Int. J. Urban Policy Plan. 2021, 108, 1029702. [CrossRef]

35. Neirotti, P.; De Marco, A.; Cagliano, A.C.; Mangano, G.; Scorrano, F. Current Trends in Smart City Initiatives: Some Stylised Facts. Cities 2014, 38, 25-36. Available online: https://www.researchgate.net/publication/260015335_Current_trends_in_Smart_City_ initiatives_Some_stylised_facts (accessed on 15 December 2021).

36. Pichlak, M. Inteligentne miasta w Polsce-rzeczywistość czy utopia? Zeszyty Naukowe. Organ. Zarzadzanie Politech. Ślaskia 2018, $127,193$.

37. Schaffers, H.; Komninos, N.; Pallot, M.; Trousse, B.; Nilsson, M.; Oliveira, A. Smart Cities and the Future Internet: Towards CooperationFrameworks for Open Innovation. 2011, pp. 431-446. Available online: https://link.springer.com/content/pdf/10.1 007\%2F978-3-642-20898-0_31.pdf (accessed on 19 November 2021).

38. Schaffers, H.; Sallstrom, A.; Komninos, N.; Pallot, M.; Trousse, B.; Senach, B.; Hielkema, H. Landscape and Roadmap of Future Internet and Smart Cities. Available online: https:/ /hal.inria.fr/hal-00769715/document (accessed on 19 November 2021).

39. Zanella, A.; Bui, N.; Castellani, A. Internet of Things for Smart Cities. IEEE Internet Things J. 2014, 1, 22-32. Available online: http://www.dei.unipd.it/ \{\}zanella/PAPER/CR_2014/IoTSmartCity2014_CR.pdf (accessed on 19 November 2021). [CrossRef]

40. Gibson, D.V.; Kozmetsky, G.; Smilor, R.W. The Technopolis Phenomenon: Smart Cities, Fast Systems, Global Networks; Rowman \& Littlefield Publishers: Lanham, MD, USA, 1992. 
41. Giffinger, R.; Fertner, C.; Kramar, H.; Kalasek, R.; Pichler-Milanoić, N.; Meijers, E. Smart Cities. Ranking of European Medium-Size Cities. In Centrel of Regional Science (SRF); University of Technology: Vienna, Austria, 2007; Available online: http:/ / www.smartcities.eu/download/smart_cities_final_report.pdf (accessed on 14 December 2021).

42. Ishida, T. Digital city Kyoto. Commun. ACM 2002, 45, 76-81. [CrossRef]

43. Mitchell, W.J. Intelligent cities. e-J. Knowl. Soc. 2007, 5, 3-8. Available online: https://uocpapers.uoc.edu/uocpapers/5/dt/eng/ mitchell.pdf (accessed on 19 December 2021).

44. Ryba, M. What Is a 'Smart City' Concept and How We Should Cal Lit in Polish. p. 84. Available online: https://www.dbc.wroc pl/Content/36867/Ryba_Czym_Jest_Koncepcja_Smart_City_2017.pdf (accessed on 20 November 2021).

45. Schuler, D. Digital Cities and Digital Citizens; Tanabe, M., van den Besselaar, P., Ishida, T., Eds.; Digital Cities II. Lecture Notes in Computer Science; Springer: Berlin, Germany, 2002; pp. 71-85.

46. Jancz, J. Miasto atrakcyjne-miastem konkurencyjnym. Refleksje 2015, 11, 39-51.

47. Arun, M. Smart Cities: The Singapore Case. p. 16. Available online: https://www.academia.edu/2875965/Smart_cities_The_ Singapore_case (accessed on 15 December 2021).

48. Hall, P. Creative Cities and Economic Development. Urban Stud. 2000, 37, 639-649. [CrossRef]

49. Azkuna, I. Smart Cities Study: International Study on the Situation of ICT, Innovation and Knowledge in Cities; The Committee of Digital and Knowledge-Based Cities of UCLG: Bilbao, Spain, 2012; p. 29.

50. Germaine, H.R. Smart Cities; The MIT Press: Cambridge, UK, 2020; pp. 134-151.

51. Glasmeier, A.; Christopherson, S. Thinking about smart cities. Camb. J. Reg. Econ. Soc. 2015, 8, 3-12. [CrossRef]

52. Leydesdorff, L.; Deakin, M. The Triple Helix Model of Smart Cities: A Neo-Evolutionary Perspective. Available online: https:// www.researchgate.net/publication/233337976_The_Triple-Helix_Model_of_Smart_Cities_A_Neo-Evolutionary_Perspective (accessed on 16 December 2021).

53. Komninos, N. Intelligent Cities: Innovation, Knowledge Systems and Digital Space; Spon Press: London, UK, $2002 ;$ pp. 143-156.

54. Ergazakis, M.; Metaxiotis, M.; Psarras, T. Towards knowledge cities: Conceptual analysis and success stories. J. Knowl. Manag. 2004, 8, 301-312. [CrossRef]

55. Kitchin, R. The Real-Time City? Big Data and Smart Urbanism. GeoJournal 2014, 79, 1-14. [CrossRef]

56. Komninos, N. Intelligent Cities: Variable Geometries of Spatial Intelligence. Intell. Build. Int. 2011, 3, 172-188. [CrossRef]

57. Komninos, N. The Architecture of Intelligent Cities: Integrating Human, Collective, and Artifcial Intelligent to Enhance Knowledge and Innovation. In Proceedings of the 2nd International Conference Intelligent Environment (IE 06), Athens, Greece, 5 July-6 2006; Available online: https://www.researchgate.net/publication/224703211_The_architecture_of_intelligent_cities_ Integrating_human_collective_and_artificial_intelligence_to_enhance_knowledge_and_innovation/link/542b8bf50cf277d58e8 a1cc2/download (accessed on 19 December 2021).

58. Labra, R.; Sanchez, M.P. National intellectual capital assessment models: A literature review. J. Intellect. Cap. 2013, 14, 582-607. [CrossRef]

59. Winters, J.V. Why are smart cities growing? Who moves and who stays. J. Reg. Sci. 2011, 51, 253-270. Available online: https:/ / onlinelibrary.wiley.com/toc/14679787/2011/51/2 (accessed on 19 November 2021). [CrossRef]

60. Kourtit, K.; Nijkamp, P. Smart Cities in the Innovation Age. Innov. Eur. J. Soc. Sci. Res. 2012, 25, 93-95. [CrossRef]

61. Kourtit, K.; Nijkamp, P.; Arribas, D. Smart cities in perspective-A comparative European study by means of self-organizing maps. Innov. Eur. J. Soc. Sci. Res. 2012, 25, 229-246. [CrossRef]

62. Stawasz, D.; Sikora-Fernandez, D.; Turała, M. Koncepcja smart city jako wyznacznik podejmowania decyzji związanych z funkcjonowaniem i rozwojem miasta. In Studia Informatica; No. 28/721; Zeszyty Naukowe Uniwersytetu Szczecińskiego: Szczecin, Poland, 2012; p. 91.

63. Energy 2020. A Strategy for Competitive, Sustainable and Secure Energy, \{SEC(2010) 1346\}. Available online: https://eur-lex. europa.eu/legal-content/EN/TXT/PDF/?uri=CELEX:52010DC0639\&from=PL (accessed on 21 November 2021).

64. Strategic Energy Technology Plan. Available online: https://ec.europa.eu/energy/topics/technology-and-innovation/strategicenergy-technology-plan_en (accessed on 19 November 2021).

65. Inteligentne Miasta i Społeczności-Europejskie Partnerstwo Innowacyjne" (nr 2013/C 280/06). Available online: https:/ / eur-lex. europa.eu/legal-content/EN/TXT/PDF/?uri=CELEX:52013IR0589\&from=PL (accessed on 19 December 2021).

66. Human Smart Cities. Inteligentne Miasta Współtworzone Przez Mieszkańców. Available online: https://www.popt.gov.pl/ strony / o-programie/wydarzenia / konkurs-dla-samorzadow-human-smart-cities-inteligentne-miasta-wspoltworzone-przezmieszkancow / (accessed on 17 December 2021).

67. Batagan, L. Smart cities and sustainability models. Rev. Inform. Econ. 2011, 15, 80-87.

68. Brondizio, E.S.; Ostrom, E.; Young, O.R. Connectivity and the governance of multilevel social-ecological systems: The role of social capital. Annu. Rev. Environ. Resour. 2009, 34, 253-278. [CrossRef]

69. Vonalo, A. Smartmentality: The Smart City as Disciplinary Strategy. Urban Stud. 2013, 51, 883-898. Available online: https: //journals.sagepub.com/doi/10.1177/0042098013494427 (accessed on 19 November 2021). [CrossRef]

70. Harrison, C.; Eckman, B.; Hamilton, R.; Hartswick, P.; Kalagnanam, J.; Paraszczak, J. Foundations for Smarter Cities. J. Res. Dev. 2010, 54, 350-365. [CrossRef]

71. Yovanof, G.S.; Hazapis, G.N. An Architectural Framework and Enabling Wireless Technologies for Digital Cities \& Intelligent Urban Environments. Wirel. Pers. Commun. 2009, 49, 445-463. 
72. Florida, R. The Rise of the Creative Class: And How It's Transforming Work, Leisure, Community, and Everyday Life; Basic Books: New York, NY, USA, 2002; pp. 22; 28-46.

73. Hall, R.E. The vision of a smart city. In Proceedings of the 2nd International Life Extension Technology Workshop, Paris, France, 28 August 2000; pp. 2-6. Available online: https:/ /www.osti.gov/servlets/purl/773961 (accessed on 21 December 2021).

74. Zygiaris, S. Smart City Reference Model: Assisting Planners to Conceptualize the Building of Smart City Innovation Ecosystems. J. Knowl. Econ. 2013, 4, 220-221. [CrossRef]

75. Nowicka, K. Smart City-Miasto Przyszłości. Gospodarka Materiałowa\&Logistyka, 2014, No 5(1233). Available online: http://yadda.icm.edu.pl/baztech/element/bwmeta1.element.baztech-9bdd45a7-fa37-4fd6-a775-8f09eff49ca5 (accessed on 19 November 2021).

76. Hollands, R.G. Will the real smart city please stand up? City: Analysis of Urban Trends, Culture, Theory. Policy Action 2008, 12, 303-320. Available online: https://www.researchgate.net/publication/248930334_Will_the_Real_Smart_City_Please_Stand_ Up/link/556744dc08aeccd777378690/download (accessed on 19 November 2021).

77. Glasmeier, A.; Christopherson, S. Przestrzenne polityki w myśli teoretycznej późnego Zygmunta Baumana. Studia Monogr. 2018, $553,220$.

78. Hollands, R.G. Critical interventions into the corporate smart city. Camb. J. Reg. Econ. Soc. 2015, 8, 64-65. [CrossRef]

79. Boulton, A.; Brunn, S.D.; Devriendt, L. Cyberinfrastructures and 'Smart' World Cities: Physical, Human and Soft Infrastructures. In International Handbook of Globalization and World Cities; Derudder, B., Hoyler, M., Taylor, P.J., Witlox, F., Eds.; Edward Elgar: Cheltenham, UK, 2011; pp. 187-199.

80. Chourabi, H.; Nam, T.; Walker, S.; Gil-Garcia, J.R.; Mellouli, S.; Nahon, K.; Pardo, T.A.; Scholl, H.J. Understanding Smart Cities: An Integrative Framework. In Proceedings of the 45th Hawaii International Conference on System Sciences, Maui, HI, USA, 4-7 January 2012; Available online: https:/ / ieeexplore.ieee.org/document/ 6149291 (accessed on 15 December 2021).

81. Colldahl, C.; Frey, S.; Kelemen, J.E. Smart Cities: Strategic Sustainable Development for an Urban World, Sweden. 2013. Available online: https:/ / www.diva-portal.org/smash/get/diva2:832150/FULLTEXT01.pdf (accessed on 15 December 2021).

82. Nam, T.; Pardo, T.A. Conceptualizing Smart City with Dimensions of Technoloy, People, and Institutions. 2011 , pp. $282-291$. Available online: https:/ /www.researchgate.net/publication/221585167_Conceptualizing_smart_city_with_dimensions_of_ technology_people_and_institutions/link/0f31752f60bf009d2f000000/download (accessed on 12 December 2021).

83. Nam, T.; Pardo, T.A. Smart City as Urban Innovation: Focusing on Management, Policy, and Context. In Proceedings of the 5th International Conference on Theory and Practice of Electronic Governance, Tallin, Estonia, 26 August-28 2011; pp. 185-194.

84. Nam, T.; Pardo, T.A. The Changing Face of a City Government: A Case Study of Philly311. Gov. Inf. Q. 2014, 31, 52-59. Available online: https:/ /www.academia.edu/29827865/The_changing_face_of_a_city_government_A_case_study_of_Philly311 (accessed on 19 December 2021). [CrossRef]

85. Cohen, B. The 3 Generations Of Smart Cities. 2015. Available online: https://www.fastcompany.com/3047795/the-3-generationsof-smart-cities (accessed on 20 November 2021).

86. Florida, R. The Historic Link between Cities and Innovation. Citylab. Available online: https://www.bloomberg.com/news/ articles/2015-12-30/the-historic-link-between-density-transportation-and-innovation (accessed on 14 December 2021).

87. Gądecki, J. Historia wielkiego wynalazku. In Polityka. Niezbędnik Inteligenta "Miasta i Ludzie"; No. 1000086; Polityka sp. Z o.o. s.k.a.: Warszawa, Poland, 2014; p. 8.

88. Nowodziński, P. Smart Cities Challenges and Opportunities. Available online: https://mitefcee.org/smart-cities-challenges-andopportunities / (accessed on 20 November 2021).

89. Eger, J.M. Smart Growth, Smart Cities, and the Crisis at the Pump A Worldwide Phenomenon. J. E-Gov. Policy Regul. 2009, 32, 47-53. [CrossRef]

90. Barrionuevo, J.M.; Berrone, P.; Ricart, J.E. Smart Cities, Sustainable Progress. IESE Insight 2011, 14, 50-57.

91. Manville, C.; Cochrane, G.; Cave, J.; Millard, J.; Pederson, J.K.; Thaarup, R.K.; Liebe, A.; Wissner, M.; Massink, R.; Kotterink, B. Mapping Smart Cities in the EU. Available online: https:/ / www.europarl.europa.eu/RegData/etudes/etudes/join/2014/50748 0/IPOL-ITRE_ET(2014)507480_EN.pdf (accessed on 15 December 2021).

92. Czupich, M.; Kola-Bezka, M.; Ignasiak-Szulc, A. Factors and barriers of implementing the concept of smart city in Poland. Studia Ekon. Zesz. Nauk. Uniw. Ekon. Katowicach 2016, 276, 101-117.

93. Giffinger, R. European Smart City Model (2007-2015), Vienna University of Technology. Available online: http:/ / www.martcities.eu (accessed on 14 December 2021).

94. Harmsen, F. Amseterdam's Intelligent Approach to the Smart City Initiative. Available online: https://s3.amazonaws.com/ marketing.mitsmr.com/PDF/EY-SponsoredViewpoint-Amsterdam.pdf (accessed on 16 December 2021).

95. Sennett, R. No One Likes a City That's Too Smart. The Guardian, 4 December 2012. Available online: https://www.theguardian. com/commentisfree/2012/dec/04/smart-city-rio-songdo-masdar(accessed on 19 November 2021).

96. Sennett, R. The Uses of Disorder: Personal Identity and City Life; Faber\&Faber: London, UK, 1996; pp. 45-55.

97. Cohen, B. The Top 10 Smart Cities on the Planet. 2014. Available online: https://www.fastcompany.com/90186037/the-top-10 -smart-cities-on-the-planet (accessed on 20 November 2021).

98. European Smart Cities 1.0, Vienna Univertisty of Technology, TUWIEN. 2007. Available online: http:/ / www.smart-cities.eu/ ranking.html (accessed on 15 December 2021). 
99. Przybyłowski, A. Smart City in the Context of Sustainable Mobility. Available online: https://journals.pan.pl/Content/103173 /PDF / 12\%20Przybylowski.pdf (accessed on 19 November 2021).

100. Obrist, B.; Pfeiffer, C.; Henley, R. Multi-Layered Social Resilience: A New Approach in Mitigation Research. 2010, pp. 283-293. Available online: https:/ / www.nccr-north-south.unibe.ch/Upload/13_Obrist.pdf (accessed on 2 February 2022).

101. Goldstein, B. Resilience to surprises through communicative planning. Ecol. Soc. 2009, 14, 33. [CrossRef]

102. Innes, J.E.; Booher, D.E. Planning with Complexity. An Introduction to Collaborative Rationality for Public Policy, 1st ed.; Imprint Routledge: London, UK, 2010; pp. 20-43.

103. Polski Komitet Normalizacyjny, PN-ISO 37120:2015-03. 2016. Available online: https://www.pkn.pl/strefa-klienta/produkty-iuslugi/certyfikacja-inteligentne-miasta (accessed on 15 December 2021).

104. Smart City Index 2021, A Tool for Action, an Instrument for Better Lives for All Citizens; IMD, Singapore University of Technology and Design: Singapore, 2021.

105. Cohen, B. What Exactly Is a Smart City? 2012. Available online: http://www.fastcoexist.com/1680538/what-exactly-is-a-smartcity (accessed on 29 November 2021).

106. Smart Cities Maturity Model and Self-Assessment Tool Guidance Note for completion of Self-Assessment Tool October 2014. Smart Cities Readiness 2014, 6-12. Available online: https://static1.squarespace.com/static/5527ba84e4b09a3d0e89e14d/t/5898 9b97e58c62ed8acd90be/1486396339725/Government_SmartCitiesMaturity_Official.pdf (accessed on 19 November 2021).

107. Thesis, D.; Villa-Arrieta, M. Energy Sustainability of Smart City, Barcelon 2019. Available online: https://www.tesisenred.net (accessed on 17 November 2021).

108. Stallman, R.M. Why Open Source Misses the Point of Free Software. GNU, 2015. Available online: http://www.gnu.org/ philosophy / open-source-misses-the-point.html (accessed on 19 November 2021).

109. Węcławowicz, G. Urban Development in Poland, from the Socialist City to the Post-Socialist and Neoliberal City. 2016 , pp. 65-82. Available online: http:/ / rcin.org.pl/Content/62816/WA51_81767_151633-r2016_Urban-Development-in.pdf (accessed on 27 November 2021).

110. Allwinkle, S.; Cruickshank, P. Creating Smarter Cities: An Overview. J. Urban Technol. 2011, 18, 1-16. [CrossRef]

111. Montgomery, H. Miasto Szczęśliwe; Wysoki Zamek: Kraków, Poland, 2015; pp. 129-135.

112. Albino, V.; Berardi, U.; Dangelico, R.M. Smart Cities: Definitions, Dimensions, and Performance. Available online: http: //cl.uw.edu.pl/dok/smart_cities.pdf (accessed on 15 December 2021).

113. Woetzel, J.; Remes, J.; Boland, B.; Lv, K.; Sinha, S.; Strube, G.; Means, J.; Law, J.; Cadena, A.; Tann, V. Smart Cities: Digital Solutions for a More Livable Future. Executive Summary, 2018. Available online: https:/ /www.mckinsey.com/business-functions / operations / our-insights/smart-cities-digital-solutions-for-a-more-livable-future(accessed on 19 December 2021).

114. Forest, F.; Lavoisy, O.; Eurich, M.; van Gurp, J.; Wilson, D. Roadmap for real world Internet applications: Socioeconomic scenarios and design recommendations. In Towards the Future Internet: A European Research Perspective; Tselentis, G., Domingue, J., Galis, A., Gavras, A., Hausheer, D., Krco, S., Lotz, V., Zahariadis, T., Eds.; IOS Press: Amsterdam, The Netherlands, 2009 ; pp. 325-334.

115. Coe, A.; Paquet, G.; Roy, J. E-governance and smart communities: A social learning challenge. Soc. Sci. Comput. Rev. 2001, 19, 80-93. [CrossRef]

116. Dirks, S.; Gurdgiev, C.; Keeling, M. Smarter Cities for Smarter Growth. How Cities Can Optimize Their Systems for the Talent-Based Economy. IBM Global Business Services, 2010. Available online: https://www.ibm.com/downloads/cas/ 8NEWPLZ1(accessed on 15 December 2021).

117. Anthopoulos, L.; Fitsilis, P. From Online to Ubiquitous Cities: The Technical Transformation of Virtual Communities, Greece. In Next Generation Society: Technological and Legal Issues, Proceedings of the Third International Conference on e-Democracy, Athens, Greece, 23-25 September 2009; Springer: Berlin/Heidelberg, Germany, 2010; Volume 26, pp. 360-372. Available online: https: / / eudl.eu/pdf/10.1007/978-3-642-11631-5_33 (accessed on 15 December 2021). 